\title{
Correction to: Monte Carlo fingerprinting of the terrestrial sources of different particle size fractions of coastal sediment deposits using geochemical tracers: some lessons for the user community
}

\author{
Hamid Gholami ${ }^{1}$ - Ebrahim Jafari Takhti Najad ${ }^{1} \cdot$ Adrian L. Collins $^{2} \cdot$ Aboalhasan Fathabadi $^{3}$
}

Published online: 15 June 2019

(C) Springer-Verlag GmbH Germany, part of Springer Nature 2019

Correction to: Environmental Science and Pollution Research (2019) 26:13560-13579 https://doi.org/10.1007/s11356-019-04857-0

The original publication of this paper contains a mistake.

The correct University and City name of the 3rd affiliation is shown in this paper.

Pulisher's note Springer Nature remains neutral with regard to jurisdictional claims in published maps and institutional affiliations

The online version of the original article can be found at https://doi.org/ $10.1007 / \mathrm{s} 11356-019-04857-0$

Hamid Gholami

hgholami@hormozgan.ac.ir

$\triangle$ Adrian L. Collins

adrian.collins@rothamsted.ac.uk

1 Department of Natural Resources Engineering, University of Hormozgan, Bandar-Abbas, Hormozgan, Iran

2 Sustainable Agriculture Sciences Department, Rothamsted Research, North Wyke, Okehampton, Devon EX20 2SB, UK

3 Department of Range and Watershed Management, Gonbad Kavous University, Gonbad Kavous, Golestan, Iran 